BIOMEDICAL AND BIOSOCIAL ANTHROPOLOGY
$\begin{gathered}\text { Official Journal of the International Academy } \\ \text { of Integrative Anthropology } \\ \text { journal homepage: http://bba-journal.com }\end{gathered}$

\title{
Features of indicators of crus rheogram in practically healthy teenagers of different somatotypes
}

Hmel L. L., Gnenna V. O., Serebrennikova O. A., Smolko N. M.

National Pirogov Memorial Medical University, Vinnytsya, Ukraine

\section{ARTICLE INFO}

Received: 7 September, 2018

Accepted: 2 November, 2018

UDC: 616-071.2:613.4:611.9:613.

956:575.191

\section{CORRESPONDING AUTHOR}

e-mail: liliako@i.ua

Hmel L. L.
Norms for assessing the functional state of the peripheral vascular system are developed, as a rule, without regard to age, gender and somatotype. The purpose of the study is to establish features of the indicators of crus rheogram in practically healthy girls and boys of different somatotypes, residents of the Podillia region of Ukraine. Rheographic indicators of the cohort of 108 practically healthy girls aged from 12 to 15 years old and 103 boys aged from 13 to 16 years and 103, urban residents of the Podillia region of Ukraine, were determined using a cardiology computer diagnostic complex. Anthropometric survey was conducted in accordance with the scheme of V. V. Bunak (1941). To evaluate the somatotype of adolescents, the mathematical scheme of J. Carter and B. Heath (1990) was used. The statistical processing of the obtained results was carried out in the license package "Statistica 5.5" using nonparametric methods for evaluating the obtained results. As a result of the research, it was found that most of the amplitudes and some of the derived indicators of the crus rheogram in girls of the mesomorphic somatotype are significantly lower or tend to be smaller than those of other somatotypes, while the time of the rising part of the rheogram and the time of slow blood filling are significantly higher than at representatives of an ectomorphic somatotype. In boys of mesomorphic somatotype, the basic impedance and amplitude of the systolic wave and the average speed of fast and slow blood flow of the rheogram are significantly lower or tend to be lower than those of other somatotypes, while the time of the ascending part and fast blood flow of rheograms and the diastolic index are significantly greater than in the representatives of the ecto-mesomorphic somatotype. It has also been found that almost half of the amplitude and derivative indices are significantly higher in girls than in boys of corresponding somatotypes, and most of the time - on the contrary, in boys, than in girls of corresponding somatotypes. Thus, indicators of crus rheogram in practically healthy girls and boys of different somatotypes, inhabitants of the Podillia region of Ukraine have pronounced differences mainly between the representatives of mesomorphic and ectomorphic somatotypes. Established pronounced manifestations of sexual dimorphism of indicators of crus rheogram between adolescents of corresponding somatotypes.

Keywords: indicators of crus rheogram, somatotype, practically healthy girls and boys, sexual differences.

\section{Introduction}

Despite the considerable efforts of world medicine, the problem of successful treatment of lower limb vessels is still far from being solved. Thus, the successes of modern angiology led to an increase in the life expectancy of patients, which in turn led to an increase in the number of late complications of this pathology $[6,10]$. First of all, they create a threat to early disability, worsen the quality of life and reduce its duration [14, 17, 26, 27].

To date, it has been established that vascular diseases of the lower extremities develop more often in patients who became ill both in childhood and in adolescence [1, 8]. This indicates the need to develop effective methods of prevention and treatment of vascular complications already in the early stages of the disease $[11,23,28]$. That is why, specialists who solve these tasks, should focus on the establishment of age standards and effective prediction of the occurrence of these disorders in children and adolescents [13, 18]. 
To evaluate the state of peripheral circulation, it is best to use the rheographic method. Its important advantage is the ability to evaluate the total blood flow to the tissues, for example, due to developed collaterals. In addition, blood circulation of several vascular areas, including symmetrical ones, is also simultaneously investigated, which makes it possible to easily detect circulatory disorders. This method significantly helps to correctly diagnose and, especially, for the current assessment of changes in blood circulation, including during functional tests [32].

Despite all the benefits of the method, the issue of hyperdiagnosis of vascular disease of the lower extremities in persons of different sex, age and somatotype by the results of the rheographic study remains relevant. Incorrect interpretation of the rheogram leads to hyperdiagnosis of serious illnesses and, consequently, to iatrogenesis and unreasonable limitation of physical activity and incorrect decision of expert questions. Most of the experimental and clinical studies performed on the diagnosis and treatment of lesions of the lower extremities from the side of the vascular bed relate mainly to the adult organism [4, 22, 24, 29]. A norm for assessing the functional state of the peripheral vascular system of adolescents were developed, as a rule, without somatotype and gender [9, 24, 25].

The purpose of the study is to establish features of the indicators of crus rheogram in practically healthy girls and boys of different somatotypes, residents of the Podillia region of Ukraine.

\section{Materials and methods}

After the preliminary questioning and instrumental and clinical-laboratory examinations on the basis of the research center of National Pirogov Memorial Medical University, Vinnytsya were selected 103 practically healthy boys aged 13 to 16 years old and 108 girls aged 12 to 15 years old, urban residents of the Podillia region of Ukraine.

Rheographic indicators of crus were determined using a cardiological computer diagnostic complex [35], which provides simultaneous recording of the electrocardiogram, phonocardiography, the main and differential tetrapolar rheogram and the measurement of blood pressure. For registration, tape rheovasographic electrodes TE.293.06301 were used, of OJSC "NII REMA" production type "tape measure", which were superimposed on the edges of the investigated sections of the limbs. The study was conducted in a horizontal position of the patient after a 10-15 minute rest on the attic in a room with an air temperature of 20-22 ${ }^{\circ} \mathrm{C}$. Before the registration, the electrodes and the investigated areas in the places of electrode overlay were treated with an alcohol, and then a physiological solution to reduce the resistance of the electrode-skin contact. Before each measurement, the device performed an automatic calibration with the quality control of the electrode overlay. The measuring current - $1.8 \mathrm{~mA}$, the current frequency $80 \mathrm{kHz}$. For the analysis $15 \mathrm{~s}$ rheogram records were used with subsequent program averaging of all periods of oscillation. As a result of processing rheograms, the characteristic points on the curve were automatically determined, the main indicators were determined, the conclusion about the condition of the circulatory system of the investigated area was formed.

Anthropometric survey was conducted in accordance with the scheme of V. V. Bunak [5]. To evaluate the somatotype of adolescents, the mathematical scheme of J. Carter and B. Heath [7] was used.

Statistical processing of the obtained results was carried out in the license package "Statistica 5.5" using nonparametric methods for evaluating the obtained results.

\section{Results}

Among the amplitude indicators of crus rheogram in girls of different somatotypes, the following changes are typical: relatively ( $p<0.05-0.01$ ) lower values of the amplitude of the systolic wave of the rheogram and rapid blood flow of the rheograms in mesomorphs than in ectomorphs and ectomesomorphs; relatively $(p<0.05)$ lover value of the amplitude of the diastolic wave of rheograms in mesomorphs than in ectomorphs; expressed tendency $(p=0.057)$ to the lower values of the basic impedance in the mesomorphs compared to the ectomorphs (Table 1). The following changes in the amplitude indices of the crus rheogram attract attention in boys: the values of the basal impedance in mesomorphs are significantly lower than in ectomorphs $(p<0.01)$, and in the ecto-mesomorphs the tendency $(p=$ $0.070)$ to greater values than in the mesomorphs; relatively $(p<0.05)$ lower values of the amplitude of the systolic wave of the rheogram in mesomorphs than in ectomorphs (see Table 1).

When comparing the amplitude indicators of the crus rheogram between girls and boys of the corresponding somatotypes, the values of the following indices established significantly higher: basic impedance $(p<0.001)$ in girls of different somatotypes; amplitudes of incisure of rheograms $(p<0.05)$ in girls mesomorphs and ectomorphs; the amplitude of fast blood flow of rheograms $(p<0.05)$ in boys mesomorphs (see Table 1).

Among the time indicators of the crus rheogram in girls of different somatotypes, the following changes are typical: significantly higher $(p<0.05)$ values of the time of the ascending part of the rheogram and the time of slow blood flow of the rheograms in mesomorphs than those of the ectomorphic somatotype (see Table 1). Boys have the following changes in the time indicators of the crus rheogram: the higher values of the time of the rising part of the rheogram and the time of fast blood flow to the rheograms in the mesomorphs are significantly higher $(p<0.05-0.01)$ than in the ecto-mesomorphs and the tendency towards higher values $(p=0.069)$ of the time of the rising part than of ectomorphs (see Table 1).

When comparing time indicators of crus rheogram between girls and boys, of corresponding somatotypes established significantly higher, or the tendency towards 
Hmel L. L., Gnenna V. O., Serebrennikova O. A., Smolko N. M.

higher values of the following parameters: cardiac cycle duration $(p<0.01-0.001)$ and time of the downward part of the rheogram in boys of different somatotypes; time of the rising part of the rheogram ( $p<0.05-0.01)$ in boys mesomorphs and ectomorphs; time of fast blood-filling rheograms in boys ectomorphs $(p<0.05)$ and mesomorphs $(p=0.056)$ (see Table 1).

Among the derivative indicators of crus rheogram in girls of different somatotypes the following changes are typical: significantly ( $p<0.01-0.001)$ lower values of the average speed of fast and slow blood flow of rheograms in girls of mesomorphs than in girls of other somatotypes (see Table 1). In boys attract attention the following changes in the derivatives of the crus rheogram: significantly $(p<0.05)$ greater diastolic index values in mesomorphs than in ectomesomorphs; relatively ( $p<0.05$ ) lower values of mean speeds of fast rheogram in boys mesomorphs than in ectomorphs and a slight tendency $(p=0.076)$ to lower values in comparison with ecto-mesomorphs; relatively $(p<0.05$ 0.01 ) lover values of mean velocity of slow blood filling of the crus in the mesomorphs are lower than those of other somatotypes (see Table 1).

Comparison of the derived indicators of crus rheogram between girls and boys of the corresponding somatotypes has established significantly higher values of the following indicators: the dicrotic index $(p<0.05-0.01)$ in girls mesomorphs and ectomorphs; the index of tone of all arteries ( $p<0.05-0.01)$ in girls mesomorphs and ecto-mesomorphs; indicator of the tone of the arteries of middle and small diameter $(p<0.05-0.001)$ in girls of different somatotypes (see Table 1).

\section{Discussion}

Adolescence is the period of the most intense reorganization of the body. From how the genetically determined program of human development is implemented at this stage, its future health depends in many respects. Incorrect interpretation of normative rheographic data in adolescence is noted by the authors of many well-known manuals [20, 34]. For a long time, more attention was paid to young people in connection with the prize to the armed forces, therefore, the norms developed during the examination of young men, were used for young women, without taking into account the age peculiarities of development and the formation of their cardiovascular system [2, 12].

The authors of the research devoted to the development of functional criteria for assessing the circulation of lower extremities in adolescents emphasize that the range of rules for this age group is very broad [30, 33]. At the same time, in the literature less attention is paid to the causes of these changes. The assumptions about the mechanisms underlying the morpho-functional changes of the vessels of the lower extremities are stated. It is an intensive growth of vessels, activation of the hypothalamic-pituitary-adrenal gland system and associated vegetative changes, electrolyte
Table 1. Changes in rheogram crus performance of adolescents of different somatotypes.

\begin{tabular}{|c|c|c|c|c|c|c|}
\hline \multirow{2}{*}{ Indicators } & \multicolumn{3}{|c|}{ Girls } & \multicolumn{3}{c|}{ Boys } \\
\hline & mes & ec & ec/mes & mes & ec & ec/mes \\
\hline G_Z (Ohm) & $\downarrow$ & $\uparrow$ & & $\mathrm{q} \downarrow$ & $\mathrm{p}$ & $\uparrow$ \\
\hline G_H1 (Ohm) & $\mathrm{q}$ & $\mathrm{p}$ & $\mathrm{p}$ & $\mathrm{q}$ & $\mathrm{p}$ & \\
\hline G_H2 (Ohm) & & & & & & \\
\hline G_H3 (Ohm) & $\mathrm{q}$ & $\mathrm{p}$ & & & & \\
\hline G_H4 (Ohm) & $\mathrm{q}$ & $\mathrm{p}$ & $\mathrm{p}$ & & & \\
\hline G_C (s) & & & & & & \\
\hline G_A (s) & $\mathrm{p}$ & $\mathrm{q}$ & & $\mathrm{p} \uparrow$ & $\downarrow$ & $\mathrm{q}$ \\
\hline G_B (s) & & & & & & \\
\hline G_A1 (s) & & & & $\mathrm{p}$ & & $\mathrm{q}$ \\
\hline G_A2 (s) & $\mathrm{p}$ & $\mathrm{q}$ & & & & \\
\hline G_H2H1 (\%) & & & & & & \\
\hline G_H3H1 (\%) & & & & $\mathrm{p}$ & & $\mathrm{q}$ \\
\hline G_H4A1 (Ohm/s) & $\mathrm{q}$ & $\mathrm{p}$ & $\mathrm{p}$ & $\mathrm{q} \downarrow$ & $\mathrm{p}$ & $\uparrow$ \\
\hline G_H1H4A2 (Ohm/s) & $\mathrm{q}$ & $\mathrm{p}$ & $\mathrm{p}$ & $\mathrm{q} \downarrow$ & $\mathrm{p}$ & $\mathrm{p}$ \\
\hline G_AC (\%) & & & & & & \\
\hline G_A1C (\%) & & & & & & \\
\hline G_A2C (\%) & & & & & & \\
\hline G_A1A2 (\%) & & & & & & \\
\hline
\end{tabular}

Notes: mes - mesomorphic somatotype; ec - ectomorphic somatotype; ec/mes - ecto-mesomorphic, or meso-ectomorphic somatotype; $\uparrow$ or $\downarrow$ - the value of the relevant indicators within the respective groups of boys or girls have a slight tendency to higher or lower values; $\uparrow$ or $\downarrow$ - the value of the relevant indicators within the respective groups of boys or girls tends to higher or lower values; $p r$ or $q \mathrm{~s}$ - significant differences between the respective indicators in the groups of boys or girls; - significant differences in the performance of the respective somatotypes between boys or girls (higher rates are noted); - trends in the differences between boys or girls in the corresponding somatotypes (higher rates are noted); G - rheographic indicators of crus; _Z - basic impedance; _H1 - amplitude of the systolic wave; _H2 - incisure amplitude; _ H3 - amplitude of the diastolic wave; _H4 - the amplitude of rapid blood flow; _C - duration of the heart cycle; A - time of the ascending part; $B$ - time of the downward part; _A1 - time of fast blood filling; _A2 - time of slow blood flow; _H2 1 1 - dicrotic index; _H3H1 - diastolic index; _H4A1 - average speed of rapid blood flow; _H1H4A2 - the average speed of slow blood flow; AC - index of tone of all arteries; A1C - index of tone of arteries of large diameter; _A2C - index of tone of arteries of medium and shallow diameter; $A \bar{A} 1 \mathrm{~A} 2$ - ratio of arteries tones.

imbalance, and also features of the stature [21, 31]

Adolescents of the same calendar age cannot be considered as a homogeneous group. They may be at different stages of puberty development and therefore have a different degree of morphofunctional maturity. Accumulate data on the dependence of morphofunctional parameters on the rate of puberty development; from biological, not from a calendar age. The interconnection of hemodynamic parameters with the types of constitution, biological age and hormonal phenotype of young women and young men [3, 
15] is traced. The rheographic diagnostic algorithms used up till now do not take into account these features.

In connection with the foregoing it seems urgent to consider the features of hemodynamics of the vessels of the lower extremities in persons of adolescence age, evaluating the results depending on the type of body and gender.

In analyzing the features of the rheograms of crus in practically healthy teens of different somatotypes, we established the following changes:

- somatotypological features of girls crus rheograms: 1) in most cases, the amplitude indices in mesomorphs are significantly lower, or tend to be less than those of ecto- and ecto-mesomorphs (with the exception of the incisure amplitude); 2) the time of the ascending part of the rheogram and the time of slow blood filling in mesomorphs are significantly greater than that of ectomorphs; 3 ) the average speed of fast and slow blood filling in mesomorphs is significantly less than that of ecto- and ecto-mesomorphs;

- somatotypological features of crus rheograms in boys: 1) the basic impedance and amplitude of the systolic wave in mesomorphs are significantly lower, or tend to be less than those of ecto- and ecto-mesomorphs; 2) the time of the ascending part and the rapid blood flow to rheograms in mesomorphs are significantly greater than that of ectomesomorphs; 3 ) the average speed of fast and slow blood flow to rheograms in mesomorphs is significantly lower or tend to be lower than that of ecto and ecto-mesomorphs, and the diastolic index in mesomorphs is significantly greater than that of ecto-mesomorphs;

- gender-somatotypological peculiarities of the crus rheograms: 1) in girls of all somatotypes, the basic impedance is significantly greater than that of boys and attracts the attention of significantly higher values of the incisure amplitude in girls mesomorphs and ectomorphs, as well as the amplitude of rapid blood flow in boys mesomorphs; 2) significantly higher, or have tendency towards higher values of all time indicators in boys of mesomorphic and ectomorphic somatotypes, as well as the duration of the heart cycle and the time of the downward part of the rheogram in boys ectomesomorphs; 3) significantly higher, or have tendency towards higher values of the dicrotic index in girls of mesomorphic and ectomorphic somatotypes, the index of tone of all arteries in young women mesomorphs and ecto-mesomorphs, as well as the index of tone of arteries of middle and small diameter in girls of all somatotypes.

I. M. Kyrychenko [16] and V. M. Moroz et al. [19] proved that

\section{References}

[1] Agrawal, K., \& Eberhardt, R. T. (2015). Contemporary medica management of peripheral arterial disease: a focus on risk reduction and symptom relief for intermittent claudication. Cardiol. Clin., 33(1), 111-137. doi: 10.1016/j.ccl.2014.09.010

[2] Ahimastos, A. A., Pappas, E. P., Buttner, P. G., Walker, P. J., Kingwell, B. A., \& Golledge, J. (2011). A meta-analysis of the outcome of endovascular and noninvasive therapies in the treatment of intermittent claudication. J. Vasc. Surg., 54(5), 1511-1521. doi: 10.1016/j.jvs.2011.06.106 the magnitude of the indicators of central hemodynamics and all the indicators obtained with the tetrapolar rheocardiography method, both in boys and girls, most often differed in adolescents with mesomorphic somatotype, which coincides with the results we obtained.

Bogachyuk O. P. and Shevchenko V. M. [4], as in our studies, proved that in girls the maximum differences between the parameters of rheoencephalography are most often established in persons with mesomorphic somatotype, but in boys of different somatotypes, the true differences between the parameters of rheoencephalography are not installed at all.

In the body of adolescents morphofunctional and neuroendocrine changes occur, which are reflected in the activity of all organs, including the state of the vascular system of the lower extremities. Therefore, a comprehensive rheographic study of the features of peripheral hemodynamics in individuals of a certain age, sexual and constitutional group will help to identify group-specific markers that reflect the pre-nosological stages of the formation of angiopathies. This will allow for the development of recommendations for their detection, correction and prevention.

\section{Conclusions}

1. Most of the amplitudes and some of the derivative indicators of crus rheogram in girls of the mesomorphic somatotype are significantly lower or tend to be smaller than those of other somatotypes, while the time of the rising part of the rheogram and the time of slow blood filling are significantly greater than those of the ectomorphic somatotype.

2. The basic impedance and amplitude of systolic wave and the average speed of fast and slow blood flow of rheograms in boys of mesomorphic somatotype are significantly lower or tend to be lower than those of other somatotypes, while the time of the ascending part and fast blood flow of rheograms and diastolic index are significantly higher than in representatives of the ecto-mesomorphic somatotype.

3. Established pronouncements of sexual dimorphism indicators of crus rheogram among adolescents of corresponding somatotypes: almost half of the amplitude and derivative indices are significantly higher in girls of different somatotypes, and most of the time - in boys of different somatotypes.

[3] Azhim, A., Akioka, K., Akutagawa, M., Hirao, Y., Yoshizaki, K., Obara, S., ... Kinouchi, Y. (2007). Effect of gender on blood flow velocities and blood pressure: role of body weight and height. Conf. Proc. IEEE Eng. Med. Biol. Soc., 2007, 967-970. doi: 10.1109/IEMBS.2007.4352453

[4] Bogachuk, O. P., \& Shevchenko, V. M. (2007). Changes in the parameters of the rheoencephalogram in urban adolescents in the Podillia region of Ukraine, depending on the characteristics of the somatotype. Biomedical and Biosocial 
Anthropology, 8, 45-49.

[5] Bunak, V. V. (1941). Anthropometry: a practical course. M.: Uchpedgiz.

[6] Camargo-Arias, E., Aponte-Rodriguez, J., Banchs-Pieretti, H., \& Altieri-Nieto, P. I. (2015). Screening for Peripheral Arterial Disease. Boletin de la Asociacion Medica de Puerto Rico, 107(3), 95-97. PMID: 26742205

[7] Carter, J. L., \& Heath, B. H. (1990). Somatotyping - development and applications. Cambridge University Press. ISSN 09570306

[8] Criqui, M. H., \& Aboyans, V. (2015). Epidemiology of peripheral artery disease. Circulation research, 116(9), 1509-1526. https://doi.org/10.1161/CIRCRESAHA.116.303849

[9] Dilenyan, L. P., Bagriy, A. S., Dilenyan, L. P., Belkaniya, G. S., Bagriy, A. S., Korepanov, S. K., ... Puhalskaya, L. G. (2015). Anthropophysiological characteristics of the "hemodynamic model" of the age dynamics of blood circulation in humans. Modern problems of science and education, 2(2), 26-34.

[10] Ferreira, A. C., \& Macedo, F. Y. B. (2010). A review of simple, non-invasive means of assessing peripheral arterial disease and implications for medical management. Annals of medicine, 42(2), 115-126. https://doi.org/10.3109/07853890903521070

[11] Fowkes, F. G. R., Aboyans, V., Fowkes, F. J., McDermott, M. M., Sampson, U. K., \& Criqui, M. H. (2017). Peripheral artery disease: epidemiology and global perspectives. Nature Reviews Cardiology, 14(3), 156-170.

[12] Fronek, A., Criqui, M. H., Denenberg, J., \& Langer, R. D. (2001). Common femoral vein dimensions and hemodynamics including Valsalva response as a function of sex, age, and ethnicity in a population study. Journal of vascular surgery, 33(5), 10501056. doi: $10.1067 / \mathrm{mva} .2001 .113496$

[13] Hennion, D. R., \& Siano, K. A. (2013). Diagnosis and treatment of peripheral arterial disease. Am. Fam. Physician., 88(5), 306-310.

[14] Hirsch, A. T., Hartman, L., Town, R. J., \& Virnig, B. A. (2008). National health care costs of peripheral arterial disease in the Medicare population. Vasc. Med., 13(3), 209-215. doi: 10.1177/ $1358863 \times 08089277$

[15] Kapilevich, L. V., Kabachkova, A. V., \& Dyakova, E. Yu. (2009). Age morphology: Tutorial. Tomsk: Tomsk State University.

[16] Kyrychenko, I. M. (2002). Features of the amplitude and temporal indices of thoracic rheograms in adolescents, depending on age, gender and somatotype. Reports of morphology, 8(2), 329-337.

[17] Komarova, L. N., Ryakhin, R. N., Aliev, F. S., \& Zvezda, S. A. (2018). Ten-year results of varicose veins treatment. The Russian Archives of Internal Medicine, 3, 215-218.

[18] McDermott, M. M. (2015). Lower extremity manifestations of peripheral artery disease: the pathophysiologic and functional implications of leg ischemia. Circulation research, 116(9), 1540-1550. https://doi.org/10.1161/CIRCRESAHA.114.303517

[19] Moroz, V. M., Gunas, I. V., Kyrychenko, I. M., Saraphinyuk, L. A., \& Kostenko, M. P. (2003). Changes in some indicators of thoracic rheograms in adolescents, depending on the characteristics of the somatotype. The article is presented in the chronological index of printed works for the period from 1990 to 2003 " Bibliography of scientists of the Academy of Medical and Technical Sciences of Ukraine ", KhmelnitskyVinnytsia (pp. 80-86). Khmelnitsky-Vinnytsia: [b.v.].

[20] Nead, K. T., Cooke, J. P., Olin, J. W., \& Leeper, N. J. (2013). Alternative ankle-brachial index method identifies additional at-risk individuals. Journal of the American College of Cardiology, 62(6), 553-559. doi: 10.1016/j.jacc.2013.04.061
[21] Olson, T. P., Schmitz, K. H., Leon, A. S., \& Dengel, D. R. (2006). Vascular structure and function in women: relationship with body mass index. American journal of preventive medicine, 30(6), 487-492. doi: 10.1016/j.amepre.2006.02.006

[22] Proctor, D. N., Le, K. U., \& Ridout, S. J. (2005). Age and regional specificity of peak limb vascular conductance in men. Journal of Applied Physiology, 98(1), 193-202. doi: 10.1152/ japplphysiol.00704.2004

[23] Rada, C., Oummou, S., Merzouk, F., Amarir, B., Boussabnia, G., Bougrini, H., ... \& Elhattaoui, M. (2016). Ankle-brachial index screening for peripheral artery disease in high cardiovascular risk patients. Prospective observational study of 370 asymptomatic patients at high cardiovascular risk. Journal des maladies vasculaires, 41(6), 353-357. doi: 10.1016/ j.jmv.2016.10.003

[24] Ridout, S. J., Parker, B. A., \& Proctor, D. N. (2005). Age and regional specificity of peak limb vascular conductance in women. Journal of Applied Physiology, 99(6), 2067-2074. doi: 10.1152/japplphysiol.00825.2005

[25] Roumia, M., Aronow, H. D., Soukas, P., Gosch, K., Smolderen, K. G., Spertus, J. A., \& Abbott, J. D. (2017). Sex differences in disease-specific health status measures in patients with symptomatic peripheral artery disease: Data from the PORTRAIT study. Vascular Medicine, 22(2), 103-109. https:/ /doi.org/10.1177/1358863X16686408

[26] Shvalb, P. G., \& Uhov, Yu. I. (2009). Pathology of venous return from the lower extremities. Ryazan: "Tigel".

[27] Szuba, A., Oka, R. K., Harada, R., \& Cooke, J. P. (2006). Limb hemodynamics are not predictive of functional capacity in patients with PAD. Vascular medicine, 11(3), 155-163. https:/ /doi.org/10.1177/1358863×06074828

[28] Tabatabaeifar, S., Frost, P., Andersen, J. H., Jensen, L. D., Thomsen, J. F., \& Svendsen, S. W. (2015). Varicose veins in the lower extremities in relation to occupational mechanical exposures: a longitudinal study. Occup. Environ. Med., 72(5), 330-337. doi: 10.1136/oemed-2014-102495

[29] Tsvyntarnyi, A. V., \& Vadzuk, S. N. (2014). Features of the derivative indices of the rheogram of the thigh in healthy young men and girls of all ages. Bulletin of scientific research, 1(74), 37-39.

[30] Vadzuk, S. N., \& Tsvyntarnyi, A. V. (2015). Age features of time and amplitude rheogram data of the thigh in healthy urban boys and girls. Bulletin of scientific research, 1(78), 20-22.

[31] Vebyakova, N. A., Fadeeva, N. A., \& Feliksova, O. M. (2013). Gender features of hemodynamic reactions to loading. Basic research, 5(1), 33-37.

[32] Vereskun, Z. F., \& Vereskun, S. B. (2011). The place of rheography in the clinical diagnosis of vascular pathology. New medicine of the millennium, 1, 56-58.

[33] Vysochanskyi, O. V. (2015). Sexual peculiarities of the relationships of indices of rheovasogram with anthroposomatotypological parameters in healthy teens of mesomorphic somatotype. Abstracts are presented in the materials of the international scientific and practical conference "Medical science and practice: topical issues of interaction", (Kyiv, pp. 60-63). Kyiv: Kiev Medical Scientific Center.

[34] Cooke, J. P., \& Wilson, A. M. (2010). Biomarkers of peripheral arterial disease. Journal of the American College of Cardiology, 55(19), 2017-2023. doi: 10.1016/j.jacc.2009.08.090

[35] Zelinsky, B. O., Zlepko, S. M., Kostenko, M. P., \& Kovalchuk, B. M. (2000). Portable multifunctional device for diagnosing the vascular bed of the circulatory system. Measuring and computing engineering in technological processes, 1, 125-132. 


\section{ОСОБЛИВОСТІ ПОКАЗНИКІВ РЕОГРАМИ ГОМІЛКИ У ПРАКТИЧНО ЗДОРОВИХ ПІДЛІТКІВ РІЗНИХ СОМАТОТИПІВ} Хмель Л. Л., Гненна В. О., Серебреннікова О. А., Смолко Н. М.

Нормативи для оцінки функціонального стану периферичної судинної системи розробляються, як правило, без урахування віку, статі та соматотипу. Мета дослідження - встановити особливості показників реограми гомілки у практично здорових дівчаток і хлопчиків різних соматотипів, мешканців Подільського регіону України. Реографрічні параметри гомілки 108 практично здорових дівчаток віком від 12 до 15 років і 103 хлопчиків віком від 13 до 16 років, міських мешканців Подільського регіону України, визначені за допомогою кардіологічного комп'ютерного діагностичного комплексу. Антропометричне обстеження проведено згідно схеми В. В. Бунака (1941). Для оцінки соматотипу підлітків використовувалась математична схема J. Carter i B. Heath (1990). Статистична обробка отриманих результатів проведена в ліцензійному пакеті "Statistica 5.5" з використанням непараметричних методів оцінки отриманих результатів. В результаті проведених досліджень встановлено, що більшість амплітудних і частина похідних показників реограми гомілки у дівчаток мезоморфного соматотипу достовірно менші, або мають тенденцію до менших значень, ніж у представниць інших соматотипів, а час висхідної частини реограми та час повільного кровонаповнення - достовірно більші, ніж у представниць ектоморфного соматотипу. У хлопчиків мезоморфрного соматотипу базовий імпеданс і амплітуда систолічної хвилі та середня швидкість швидкого і повільного кровонаповнення реограми достовірно менші, або мають тенденцію до менших значень, ніж у представників інших соматотипів, а час висхідної частини і швидкого кровонаповнення реограми та діастолічний індекс - достовірно більші, ніж у представників екто-мезоморфного соматотипу. Також встановлено, що майже половина амплітудних і похідних показників достовірно більша у дівчаток, ніж у хлопчиків відповідних соматотипів, а більшість часових - навпаки, у хлопчиків, ніж у дівчаток відповідних соматотипів. Таким чином, показники реограми гомілки у практично здорових дівчаток і хлопчиків різних соматотипів, мешканців Подільського регіону України мають виражені розбіжності переважно між представниками мезоморфного та ектоморфного соматотипів. Встановлені виражені прояви статевого диморфрізму за показниками реограми гомілки між підлітками відповідних соматотипів.

Ключові слова: показники реограми гомілки, соматотип, практично здорові дівчатка та хлопчики, статеві розбіжності.

\section{ОСОБЕННОСТИ ПОКАЗАТЕЛЕЙ РЕОГРАММЫ ГОЛЕНИ У ПРАКТИЧЕСКИ ЗДОРОВЫХ ПОДРОСТКОВ РАЗНЫХ СОМАТОТИПОВ \\ Хмель Л. Л., Гненная В. О., Серебренникова О. А., Смолко Н. Н.}

Нормативы для оценки функционального состояния периферической сосудистой системы разрабатываются, как правило, без учета возраста, пола и соматотипа. Цель исследования - установить особенности показателей реограммы голени у практически здоровых девочек и мальчиков разных соматотипов, жителей Подольского региона Украины. Реографические параметры голени 108 практически здоровых девочек в возрасте от 12 до 15 лет и 103 мальчиков в возрасте от 13 до 16 лет, городских жителей Подольского региона Украины, определены с помощью кардиологического компьютерного диагностического комплекса. Антропометрическое обследование проведено согласно схеме В. В. Бунака (1941). Для оценки соматотипа подростков использовалась математическая схема J. Carter и B. Heath (1990). Статистическая обработка полученных результатов проведена в лицензионном пакете "Statistica 5.5" с использованием непараметрических методов оценки полученных результатов. В результате проведенных исследований установлено, что большинство амплитудных и часть производных показателей реограммы голени у девочек мезоморфного соматотипа достоверно меньше, или имеют тенденцию к меньшим значениям, чем у представительниц других соматотипов, а время восходящей части реограммы и время медленного кровенаполнения - достоверно больше, чем у представительниц эктоморфрнго соматотипа. У мальчиков мезоморфного соматотипа базовый импеданс и амплитуда систолической волны, средняя скорость быстрого и медленного кровенаполнения реограммы достоверно меньще, или имеют тенденцию к меньшим значениям, чем у представителей других соматотипов, а время восходящей части и быстрого кровенаполнения реограммы и диастолический индекс - достоверно больше, чем у представителей экто-мезоморфного соматотипа. Также установлено, что почти половина амплитудных и производных показателей достоверно больще у девочек, чем у мальчиков соответствующих соматотипов, а большинство временных - наоборот, у мальчиков, чем у девочек соответствующих соматотипов. Таким образом, показатели реограммы голени у практически здоровых девочек и мальчиков разных соматотипов, жителей Подольского региона Украины имеют выраженные различия в основном между представителями мезоморфного и эктоморфного соматотипов. Установлены выраженные проявления полового диморфизма по показателям реограммы голени между подростками соответствующих соматотипов.

Ключевые слова: показатели реограммы голени, соматотип, практически здоровые девочки и мальчики, половые различия. 